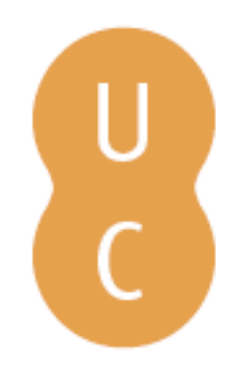

\title{
pommalina
}

Napoleão Bonaparte e Portugal: momento constitucional e imaginário político de uma geração
Autor(es):
Araújo, Ana Cristina
Publicado por: Imprensa da Universidade de Coimbra
URL
persistente:
URI:http://hdl.handle.net/10316.2/38678
DOI:
DOI:http://dx.doi.org/10.14195/978-989-26-1164-8_1
Accessed : $\quad$ 26-Apr-2023 10:29:43

A navegação consulta e descarregamento dos títulos inseridos nas Bibliotecas Digitais UC Digitalis, UC Pombalina e UC Impactum, pressupõem a aceitação plena e sem reservas dos Termos e Condições de Uso destas Bibliotecas Digitais, disponíveis em https://digitalis.uc.pt/pt-pt/termos.

Conforme exposto nos referidos Termos e Condições de Uso, o descarregamento de títulos de acesso restrito requer uma licença válida de autorização devendo o utilizador aceder ao(s) documento(s) a partir de um endereço de IP da instituição detentora da supramencionada licença.

Ao utilizador é apenas permitido o descarregamento para uso pessoal, pelo que o emprego do(s) título(s) descarregado(s) para outro fim, designadamente comercial, carece de autorização do respetivo autor ou editor da obra.

Na medida em que todas as obras da UC Digitalis se encontram protegidas pelo Código do Direito de Autor e Direitos Conexos e demais legislação aplicável, toda a cópia, parcial ou total, deste documento, nos casos em que é legalmente admitida, deverá conter ou fazer-se acompanhar por este aviso.

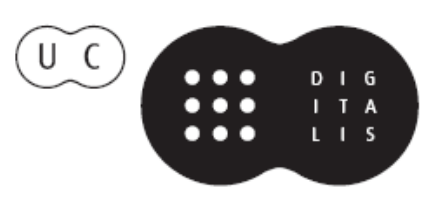


Ana Cristina Araújo

Universidade de Coimbra / Centro de História da Sociedade e da Cultura

\section{NAPOLEÃO BONAPARTE E PORTUGAL. MOMENTO CONSTITUCIONAL E IMAGINÁRIO POLÍTICO DE UMA GERAÇÃo}

Portugal teve o seu "momento Napoleão". Na aceção em que John Pocock utiliza a expressão "momento Maquiavel" para exprimir o ressurgimento e o sentido do republicanismo cívico moderno", o "momento Napoleão" de que falamos corresponde a um modus civis cosmopolita e ilustrado que se consubstancia numa precisa aspiração de mudança constitucional, portadora de valores antigos e modernos, formulada em oposição ao Antigo Regime e marcada por um horizonte de expectativa próximo, de integração de Portugal no império continental napoleónico.

Como nota preliminar do cenário político-constitucional arquitetado em 1808, convém precisar de que modo a França pontuou a conjuntura portuguesa que antecedeu a retirada da casa reinante de Bragança para o Brasil e a ocupação franco-espanhola do reino de Portugal, em novembro de 1807.

\section{Propaganda Republicana, Emigração Política e Diplomacia de Guerra}

A influência da política internacional francesa revela-se por via negocial e diplomática e por meio de intensas campanhas noticiosas e de propaganda política, agenciadas a partir do exterior, que atingem importantes setores das elites

1 POCOCK, J. G. A., The Machiavellian moment: Florentine political thought and the Atlantic republican tradition, Princepton, Princepton University Press, 1975. 
portuguesas e de emigrados franceses refugiados no país, depois da Revolução de 1789. Começando pela questão da propaganda, assinalamos a criação do Cercle Social, que, segundo informa o embaixador português em Paris, Vicente de Sousa Coutinho, tinha por objectivo difundir nos países europeus e nos domínios americanos a doutrina revolucionária. Ao abrigo do Cercle Social teriam partido, em 1791, do porto de La Rochelle com destino a Portugal Pierre Choderlos de Laclos, autor do célebre livro Les Liaisons Dangereuses, acompanhado de três jacobinos franceses. Regista ainda o mesmo embaixador que tivera notícia da edição traduzida da Constituição de 1791, com uma tiragem exorbitante, de 12000 exemplares, a cargo de Diogo Borel, destinada também ao mercado português, assim como de milhares de catecismos revolucionários, um dos quais conhecido pela designação de folha do "Père Gerard". Entretanto, em Janeiro de 1793, é preso Francisco Coelho da Silva acusado de ter redigido uma Censura à Constituição Franceza e de ter traduzido a Declaração dos Direitos do Homem e do Cidadão. Pina Manique vislumbrava o perigo da atuação de Coelho da Silva em função da natureza interclassista da receção da sua mensagem. Segundo o Intendente Geral da Polícia, "ele se introduzia entre varias qualidades de gente, que talvez por gostarem de o ouvir, tinha a facilidade de o admitirem em suas casas" ${ }^{2}$.

No quadro de iniciativas avulsas ou concertadas de internacionalização dos ideários políticos em confronto depois da Revolução, as movimentações de agentes e emissários estrangeiros em Portugal tornam-se motivo de redobrada vigilância por parte da Intendência Geral da Polícia. A mando de Pina Manique é preso, em 1791, no Porto de Lisboa, para identificação e inquirição, Luís António Martins Calhassen, oriundo da região do Languedoc, que chega a Lisboa com o cargo de secretário da embaixada de França. Porém, as credenciais de que era portador não foram reconhecidas pelo embaixador francês, conde de Châlons.

Entre outros indivíduos de incerta condição e de suspeita ligação aos revolucionários de Paris encontrava-se Thomas António Lequens que, ao desembarcar em Lisboa, se fez passar por familiar de comerciantes com o mesmo apelido

2 SORIANO, Simão José da Luz, História da Guerra Civil e do Estabelecimento do Governo Parlamentar em Portugal. Compreendendo a História Diplomatica, Militar e Politica d'este Reino desde 1772 até 1834. Primeira Epocha, tomos. I, Lisboa, Imprensa Nacional, 1866, p. 404. 
estabelecidos na capital portuguesa. Em relação a outros emissários e agentes estrangeiros de passagem pela capital portuguesa, como Kerc e Fontaine, havia suspeitas fundadas de que os contactos com os revolucionários se realizavam por intermédio de mensageiros bem colocados em Badajoz e Madrid³.

Entretanto, os esforços propagandísticos de Convenção, depois da criação, em 1793, de Comités Espagnols d'Instruction Publique, em Bayonne e Perpignan, tiveram também alguma repercussão em Portugal. Antes de ter início a campanha do Roussilhão (1793-195) - que levantou o exército espanhol auxiliado por um destacamento de tropas portuguesas contra o expansionismo da república francesa - circularam clandestinamente, em Espanha e Portugal, versões traduzidas das Constituições de 1791 e 1793 e da Declaração dos Direitos do Homem e do Cidadão, para além de inúmeros jornais estrangeiros, folhetos e catecismos revolucionários, como o famoso "Credo da República Lombarda", apreendido pelo corregedor da comarca de Barcelos, em 1797, a um advogado da terra e que começava assim: "Creyo na Republica Francesa huna e indevizivel creadora da igualdade e liberdade, no general Bonaparte, seu filho nosso único defensor" ${ }^{4}$.

Com o mesmo nexo republicano, também em Coimbra fora afixado, na Porta Férrea, um pasquim contra um dos ministros de D. João, José Seabra da Silva, e contra a monarquia, e que continha referências como esta: "o velhaco vil Seabra aos pés calquemos/ De vós os monstros tremão, trema o Trono, / Que hum dia o Trono, tudo arrazaremos" .

A esta ação revolucionária de rua, para utilizar uma expressão moderna, estiveram ligados os estudantes Alexandre Inácio Correia Soares Velho, Francisco Simões Magiorchi e outros nomes não identificados. Estes jovens desordeiros tinham elementos de ligação na capital, pois, no mesmo ano de 1797, no cais de Santarém, foram ainda apreendidos papéis sediciosos manuscritos da mesma autoria, papéis que, segundo o corregedor da comarca, tinham por objetivo "revoltar os povos e mostrar a occasião que devem aproveitar para este fim,

3 RAMOS, Luís de Oliveira, D. Maria I, Lisboa, Círculo de Leitores, 2007, p. 178.

4 ANTT, Ministério do Reino, maço, 454, caixa 569. A abreviatura utilizada nesta nota e nas seguintes corresponde ao Arquivo Nacional da Torre do Tombo.

5 ANTT, Ministério do Reino, maço 454, caixa 569. 
atacando o tribunal do Santo Officio, os seus ministros e o que he mais até o Príncipe"

Outros sinais de tensão social e de contestação política são observados, amiúde, nas praças e locais públicos da capital, conforme se colige da documentação da Intendência Geral da Polícia relativa aos anos noventa do século xviı. Reiteradas denúncias anónimas mencionam que, em ajuntamentos públicos de cariz festivo, era frequente ouvirem-se elogios e vitupérios aos revolucionários franceses, ao som de acordes da Marselhesa e de outros hinos mal compreendidos ${ }^{7}$ Ao mesmo tempo, na Praça do Comércio, núcleos de frequentadores anónimos faziam ronda "todas as tardes, pelos cafés, boticas e algumas lojas de mercadores, espalhando vozes ímpias e sediciosas" ${ }^{\text {. Davam }}$ a conhecer "os procedimentos dos franceses e do governo republicano, proferindo liberdades temerárias, e malquistando com impropérios os ministros de estado"9. Durante o período da Convenção Francesa (1792-1795), vozes anónimas, elogiavam assim, publicamente, as virtudes republicanas contra os vícios da monarquia em França. E os agitadores que se encarregavam de divulgar em Lisboa o noticiário da Revolução, admitiam mesmo a possibilidade de substituição, no velho Terreiro do Paço, da estátua equestre de D. José I por uma frondosa Árvore da Liberdade ${ }^{10}$. Estes e outros testemunhos do género, envolvendo ou não a presença de estrangeiros, fizeram alastrar, na capital, a senha de perseguição aos jacobinos, reais ou imaginários. De facto, na transição do século xviII para o século xix, o recrudescimento do policiamento urbano representava bem o verso e o reverso de uma indisfarçável politização da esfera pública em Portugal ${ }^{11}$.

Nas principais cidades do norte e do centro do país, Braga, Porto e Coimbra, informadores ocasionais e delatores ocultos alertam as autoridades civis e

6 ANTT, Ministério do Reino, maço 454, caixa 569.

7 SORIANO, Simão José da Luz, ob. cit., $1^{\text {a }}$ ep., t. 1, pp. 408-409.

8 Ofício de Pina Manique para o marquês de Ponte de Lima, datado de 1 de Outubro de 1797,

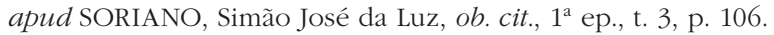

9 Idem, ibidem.

10 Ofício de Pina Manique para o marquês de Ponte de Lima, datado de 5 de Julho de 1794, apud DIAS, Graça da Silva e José Sebastião da Silva, Os primórdios da Maçonaria em Portugal, Lisboa, INIC, 1980, vol. 1, t. I, pp. 362-363.

11 ARAÚJO, Ana Cristina, A Cultura das Luzes em Portugal. Temas e Problemas, Lisboa, Livros Horizonte, 2003, pp. 92-103. 
eclesiásticas para a presença de indivíduos, jacobinos e legitimistas, suspeitos de propagarem ideias revolucionárias. A pedido do Intendente Geral da Polícia, Pina Manique, o corregedor da comarca do Porto é instado a vigiar a atividade de um grupo difuso de homens de diferentes condições sociais, formado por clérigos e leigos, burgueses e nobres, nacionais e estrangeiros que "se denominão por bem instruídos e desabuzados, e se juntão todos os dias nos passeios e casas de huns e de outros"12. No rol de suspeitos encontravam-se, segundo supunha o Intendente, "pedreiros livres que se denominão filósofos", responsáveis por obras e papeis de circulação clandestina, ajuntamentos suspeitos e actos provocatórios, como o que ocorreu em 4 de Fevereiro de 1794. Nesse dia, apareceram borrados editais do corregedor da comarca e pastorais do bispo, afixados em paredes de edifícios públicos ${ }^{13}$.

Com o passar dos anos, os motivos de suspeição e denúncia sobre a atividade clandestina dos "jacobinos" estendem-se a cidadãos e agentes da embaixada da França e até a emigrados tradicionalistas, com residência em Portugal. Os livreiros Borel, Bertrand, Aillaud, Dubié, Loup e outros são acusados, em diferentes momentos, de subverterem a ordem pública, vendendo livros proibidos ${ }^{14}$. Entre a burguesia francesa, com sólidos negócios no reino, ressaltam pela simpatia que publicamente manifestaram aos ideais da Revolução, os industriais Jacôme Ratton e Lécussan Verdier, o cravador de diamantes Louis Madry e os pintores Pierre Noel e Nicolas-Louis Delerive, entre outros nomes menos conhecidos ${ }^{15}$.

No grupo dos emigrados franceses prevalecem, todavia, os aristocratas conservadores anti-republicanos, como o conde de Coigny que representa oficialmente na corte o conde da Provença, futuro Luís XVIII; o conde de Vioménil que substitui, temporariamente, o prussiano conde de Goltz à frente do comando do exército português; o marquês de Toustain que o regente nomeou tenente-coronel de cavalaria; o conde de Novion comandante da Guarda Real de Polícia e muitas outras figuras da nobreza e do clero protegidas, durante a

12 Ofício de Pina Manique para o corregedor da comarca do Porto, o desembargador Francisco de Almada e Mendonça, datado de 4 de Janeiro de 1794 apud DIAS, Graça da Silva e José Sebastião da Silva, Os primórdios da Maçonaria em Portugal ... cit., vol. 1, t. I, p. 367, nota 1.

13 Idem, ibidem.

14 RAMOS, Luís de Oliveira, Da Ilustração ao Liberalismo. Temas Históricos, Porto, Lello \& Irmão, 1979.

15 RAMOS, Luís de Oliveira, D. Maria I, Lisboa, Círculo de Leitores, 2007. 
Convenção, pelo embaixador francês, conde de Châlons, que chegou mesmo a colaborar com a Intendência Geral da Polícia, denunciando compatriotas seus, estabelecidos ou de passagem em Lisboa, acusados de jacobinismo.

No seio do grupo de emigrados franceses, os intelectuais moderados exilados e, em especial, os membros da igreja galicana que recusaram jurar a constituição civil do clero contaram com apoio expresso dos principais membros do episcopado português. Calcula-se que em Espanha se refugiaram 5000 eclesiásticos franceses, muitos dos quais tiveram como último destino Portugal ${ }^{16}$. Aqui distribuíram-se pelas várias dioceses do reino, hospedaram-se em conventos e foram acolhidos pela fidalguia de província e pelas melhores casas aristocráticas, servindo como preceptores e mestres de meninos.

D. Francisco de Almeida Portugal, conde de Lavradio, nas suas Memórias, lembra que começara a "estudar a língua francesa com um eclesiástico francês, que tinha sido cónego de Santa Genoveva, em Paris, chamado Doisseau ou Doissot", e que, pouco depois, tivera como professores "primeiro o abade Boiret, vendeano, e depois o abade Laloir, natural de Arras, ambos eles emigrados"17.

Um outro testemunho desse tempo encontra eco no manuscrito de exílio, sem atribuição de autoria, mas escrito com toda a probabilidade por um clérigo, intitulado: "La mort de Louis Seize et de Marie-Antoniette, Roi et Reine de France, ou Tableau historique de l'origine et des progrès de la Révolution". Neste texto, as atrocidades e os excessos dos revolucionários eram justificadas pelo "fanatisme irreligieux et philosophique" que grassava em França e que se propagava vertiginosamente, ameaçando as monarquias europeias e pondo em perigo a conservação dos domínios coloniais das potências marítimas ocidentais. De acordo com esta leitura política, "le feu de la Révolution n'embrasait pas seulement la France. Il avait franchi les limites des mers. Les torches ensanglantées de la discorde avaient pénétré dans les colonies, allumées et portées par les émissaires de l'Assemblée. Elles y faisaient les plus cruels ravages"18.

\footnotetext{
16 CHAVES, Castelo Branco, A emigração francesa em Portugal durante a Revolução, Lisboa, Biblioteca Breve, 1984, p. 46.

17 LAVRADIO, Conde de, Memórias do Conde de Lavradio - D. Francisco de Almeida Portugal, Lisboa, Imprensa da Universidade, 1932, vol. 1, p. 13.

18 BRITO, Ferreira de, Revolução Francesa. Emigração e Contra-Revolução, Porto, Universidade do Porto, 1989, p. 309.
} 
Para além da proteção institucional de que gozavam os mais influentes membros da colónia francesa emigrada em Portugal, o governo de Londres garantiu apoio financeiro e diplomático a muitos dos servidores aristocráticos franceses colocados, temporariamente, ao serviço da Corte de D. Maria I. Mesmo gozando desta dupla proteção, a maioria dos membros da comunidade francesa acabou por abandonar o país antes da guerra, um outro grupo menor alistou-se no chamado "exército dos príncipes", e uma parcela residual ficou ao serviço da monarquia. Em 1798 os regimentos de emigrados e as forças inglesas que se encontravam em Portugal ascendiam a 5732 homens, isto é, representavam cerca de um quarto de todos os alistados de primeira linha ${ }^{19}$.

Depois da iniciativa do $1^{\circ}$ cônsul, Napoleão Bonaparte, de amnistiar muitos dos que se haviam exilado, e na sequência da assinatura da Concordata (1801) com a Santa Sé, o clero e a nobreza expatriados puderam livremente regressar a França ${ }^{20}$. Portanto, a colónia de emigrados franceses em Portugal foi diminuindo, em número e importância. Os nobres e oficiais incorporados no exército português que ficaram colaboraram efetivamente com Junot, antes e durante a ocupação militar francesa. E depois da rendição das forças de ocupação e da assinatura da Convenção de Sintra (30 de Agosto 1808), muitos acabaram por regressar a França, também amnistiados.

Em relação à embaixada francesa, desde o tempo em que o conde de Châlons a dirigiu com manifesta parcialidade até à missão impossível, em 1805, do embaixador Jean-Andoche Junot em Lisboa, alguns motivos de pública denúncia acabaram por converter-se em incidentes graves, do ponto de vista diplomático. Retemos apenas dois episódios que resumem o carácter dúplice da atuação da embaixada francesa antes da guerra. O primeiro incidente prende-se com a perseguição movida ao emissário diplomático da Convenção Antoine Darbault. De março a abril de 1793, o republicano Darbault viveu a salto em Lisboa, acabando por ser repatriado num navio que viria a ser apresado pelos ingleses.

O segundo incidente grave ocorre com a embaixada do general Lannes (1802-1804), um militar de carreira, que participou nas campanhas de Itália e do Egipto, que tomou parte ativa no golpe de 18 de Brumário ( 9 de Novembro de

19 CHAVES, Castelo Branco, A emigração francesa em Portugal durante a Revolução, Lisboa, Biblioteca Breve, 1984, p. 55.

20 BOUDON, Jacques-Olivier, La France et l'Europe de Napoléon, Paris, Armand Colin, 2006. 
1799) e que é destacado para Lisboa em 1802, ano da assinatura da Paz Geral de Amiens, para cumprir uma verdadeira missão ofensiva em termos diplomáticos. Depois de alguns conflitos com membros do governo, Lannes exige e consegue obter o afastamento de Vioménil do comando do exército português e a demissão do Intendente Geral da Polícia e da Alfândega Pina Manique (março de 1803). Conhecedor das intrigas da corte, da crise financeira do Estado Português, dos planos de transferência da família real para o Brasil, Lannes negoceia vantagens para comércio externo do seu país e garante o pagamento à França de avultadas contribuições de guerra por parte de Portugal.

Depois da proclamação do Império, em 1804, a hegemonia militar francesa no continente conduzirá à abertura de uma frente militar na Península Ibérica, frente que, no caso português, foi meticulosamente preparada no plano diplomático. Um cabo-de-guerra, um ex-ajudante de campo de Napoleão, o general Jean-Andoche Junot é nomeado, em 1805, embaixador em Lisboa. O homem que vinha preparar a investida militar de 1807, por sinal por ele dirigida, trazia credenciais alargadas, de tal modo que arriscou contar espingardas antes da guerra, isto é, negociou apoios, certificou-se das clivagens internas na corte, das quebras de fidelidade dos Grandes à realeza e da simpatia da elite mais politizada à causa do continente. Encontrou um grupo interessado na tradução do Código Civil francês de 1804 e estabeleceu uma rede contactos no seio das mais influentes instituições do reino.

Napoleão que se dirigia por carta ao príncipe regente D. João utilizando os epítetos de "muito amado Irmão e Primo, aliado e confederado", garantira previamente que o seu último embaixador em Lisboa iria ser recebido, em solene audiência, por um príncipe "enfeitado com um dos sete grandes cordões da Legião de Honra que o imperador lhe enviara" ${ }^{21}$. Idêntico agraciamento receberam os duques de Cadaval e de Lafões e os ministros conde de Vila-Verde e António de Araújo de Azevedo. Em suma, à medida que a tensão bélica no continente aumentava a corte portuguesa espelhava a proteção do Império, garantindo uma suposta "neutralidade" internacional e aceitando, tacitamente, proteger a França e os seus cidadãos.

21 GOTTERI, Nicole, Napoleão e Portugal (tradução de Paula Reis), Lisboa, Teorema, 2006, p. 122. 
A este compromisso de honra e de palavra correspondeu, pouco depois, D. João ao recusar declarar guerra ao exército ocupante franco-espanhol. Sete dias depois de este ter cruzado a fronteira, em 19 de Novembro de 1807, um edital régio ordenava que as autoridades locais e os agentes do poder central recebessem os franceses como amigos e protetores.

De facto, a força de ocupação dirigida por Junot progrediu lentamente no território nacional sem enfrentar resistência armada organizada. O general francês apresentou-se como 'protetor do reino', foi bem acolhido pelos membros do Conselho de Regência, recebeu cumprimentos oficiais da Guarda Real de Polícia e da Academia das Ciências, foi saudado por membros da Maçonaria e pela hierarquia eclesiástica e instalou o seu quartel-general em Lisboa. Procedeu a pequenas alterações na composição do executivo e instituiu um governo de protetorado, de molde a salvaguardar a capacidade de exercício das autoridades portuguesas.

A "submissão" dos governadores do reino e das mais altas dignidades eclesiásticas ao regime imposto por Junot correspondeu, em termos práticos, à concretização do plano tático adotado pelo príncipe regente D. João antes da partida da corte para o Brasil, plano que teve o aval de Inglaterra. Em representação do poder absoluto, a Regência acatou e cumpriu, escrupulosamente, as orientações do ministério sediado no Rio de Janeiro. De Novembro de 1807 a Junho de 1808, colaborou abertamente com os emissários de Napoleão.

\section{A Ocupação Político-Militar e o 'Momento Constitucional' Napoleónico}

Em 1 de Fevereiro de 1808 é extinto o Conselho de Regência e Napoleão, em clara violação do Tratado de Fontainebleau, destitui a Casa de Bragança e passa a reinar oficialmente em Portugal. Só a partir de Junho, quando é conhecido em Lisboa e em todas as capitais europeias o Manifesto e exposição fundada de D. João VI, e quando já se fazem sentir, do outro lado da fronteira, os ventos da revolta, a elite de poder muda de aliados e, em estreita colaboração com as massas populares, "dirige" a revolta contra o ocupante estrangeiro. A primeira aliança, congeminada com espírito de traição, evidencia a convergência tática e a coesão ideológica das classes dominantes. Nesta 
conjuntura, o colaboracionismo contribuiu, de facto, para proteger e manter atuantes as instituições do Antigo Regime ${ }^{22}$.

Não deve portanto estranhar-se que uma embaixada constituída por catorze personalidades representativas das mais importantes instituições do país - Governo do Reino, Inquisição, Universidade, Senado da Câmara de Lisboa, Ordem Militares e Junta dos Três Estados - se tenha dirigido a Bayonne para cumprimentar, em nome da nação portuguesa, o imperador dos franceses. O encontro com a "deputação portuguesa", apesar de inconclusivo, ocorreu em abril de 1808. A iniciativa desta missão partiu do poder francês que negociou com os elementos que compunham a representação os termos do pacto de aceitação do poder imperial em Portugal, termos flexíveis se tivermos em conta que, oralmente, se propôs que a dinastia de Bragança fosse reintegrada nos seus direitos, isto é, que continuasse a reinar ${ }^{23}$.

Acompanhando as movimentações destes afrancesados com mandato político de Junot, mas temendo a inércia das instituições políticas e o desfecho dos motins protagonizados pelos de mais baixa condição que começavam a surgir, os ilustrados e os liberais que se colocaram do lado da França acabaram por trilhar uma outra via, mais imediata e viável para a materialização de um vasto programa de reformas institucionais e económicas. Unidos à causa continental, resolveram peticionar, de motu proprio, ao imperador uma Constituição para Portugal.

Para além da confirmação das intenções reformistas de Napoleão em relação a Espanha, teve algum impacto no desencadear da petição constitucional destes afrancesados portugueses a intenção expressa pelo imperador de fazer vigorar em Portugal o Código de Direito Civil de 1804. Esta ideia, aliada à proposta de secularização de metade dos bens dos conventos, foi saudada com entusiasmo por este grupo. Todo o processo que envolveu a iniciativa da tradução, a escolha do tradutor e a impressão final do Código foi depois cuidadosamente silenciado e, por isso, ainda hoje se conhece mal o desfecho do caso. De qualquer modo,

22 ARAÚJO, Ana Cristina, "Revoltas e ideologias em conflito durante as Invasões Francesas", Revista de História das Ideias, vol. 7, 1985, p. 21.

23 RAMOS, Luís de Oliveira, "D. Francisco de Lemos e a deputação a Baiona”, in Estudos de História de Portugal de Homenagem a A. H. de Oliveira Marques, Lisboa, Editorial Estampa, 1983, vol. 2, pp. 273-288 e HESPANHA, António Manuel, "Bajo el signo de Napoleón. La Súplica Constitucional de 1808”, in Cuadernos de Historia Moderna, vol. VII, 2008, pp. 299-318. 
não deixa de ser surpreendente que entre a primeira indicação vinda de Paris nesse sentido e a resposta do general Junot, que dava a obra concluída e em vias de publicação, medeie pouco mais de uma semana ${ }^{24}$. A cronologia dos acontecimentos respeitantes à tradução do Código permite concluir que a ideia de imposição do código é anterior à proposta de Napoleão e que o projecto inicial e a sua concretização se inscrevem, talvez, na ação subterrânea desenvolvida por franceses residentes em Lisboa e por alguns portugueses descontentes com a situação política, tendo o projecto despontado nos anos de 1805 e 1806, durante a embaixada de Junot em Lisboa.

Quando Junot se instala na cidade, em novembro de 1807, a cooperação leal do conde de Novion, comandante da Guarda Real de Polícia, foi, desde logo, de grande importância para o estabelecimento e manutenção da ordem pública. A duquesa de Abrantes que estivera em Lisboa de abril de 1805 a dezembro de 1806 acompanhando o marido, Junot, na sua missão diplomática, guardara desse curto período de permanência na capital portuguesa uma impressiva memória da Corte e da alta sociedade portuguesa. As impressões desse tempo foram reatualizadas e confirmadas à distância, mais tarde, com informações transmitidas por carta e oralmente. Algumas delas dizem respeito a acontecimentos relevantes da missão do duque de Abrantes em Portugal, em 1807-1808. No registo diferido das Mémoires e dos Souvenirs d'une embassade ${ }^{25}$ a duquesa de Abrantes reconhece que a ação do conde de Novion, "desde há muito amigo

24 A carta de Napoleão data de 15 de Maio de 1808 e a resposta de Junot é escrita a 24 de Maio. A respeito desta missiva, não deixa de ser curioso notar que o general francês, depois de desaconselhar a introdução do direito civil napoleónico em Portugal, acrescente: "Prévoyant bien les intentions de V. M. j’avais demandé la traduction de ces differents codes: le code de procédure civile est déjà à l'impression, le code du Commerce est traduit; on s'occupe de traduire les autres, \& je les ferai imprimer sur le champ, \& répandre dans le pays, les jurisconsultes feront leurs réfléxions; quelques uns s'y attendent déjà. Je crois que la réduction des Couvens pourra s'opérer sans de grandes difficultés, ce sera cependant une des choses les plus délicates à faire dans ce pays", apud SEPÚlVEDA, Cristóvão Aires de Magalhães, Historia Organica e Politica do Exercito Português. Provas, vol XII, Lisboa, Imprensa da Universidade, 1917, pp. 201-202.

25 A obra de Laure Permon, mulher de Junot, Souvenirs d'une ambassade et d'un séjour en Espagne et en Portugal de 1808 à 1811, Paris, Ollivier, 1837, apesar da datação que tem inscrita no título respeita especialmente o período que vai de fins de abril de 1805 a dezembro de 1806 . Em rigor, em Souvenirs d'une ambassade, a autora reproduz, amplia ou abrevia os capítulos X, XI, XII, XV, XVIII, XXII a XXIX e XXXI do quinto volume das Mémoires de Madame la Duchesse d'Abrantès: souvenirs historiques sur Napoléon, la révolution, le directoire, le consulat, l'Empire et la restauration, que lhe são anteriores (1831-1835). Cf. PIWNIK, Marie-Hélène, "A Duquesa de Abrantes e Portugal. Algumas Observações" in AAVV. O Porto e as Invasões Francesas. 1809-2009, Porto, Público-CMP, 2009, vol. 1, pp. 125-156. 
da família” ${ }^{26}$, favoreceu, objetivamente, a instalação do governo francês de ocupação. Do mesmo modo, torna irrefutável a aspiração de poder pessoal do marido, aspiração secundada pelo voto favorável de um punhado de diplomatas, nobres, eclesiásticos e magistrados. Em cumprimento desse desígnio, afirma que o cunhado, "o senhor Geouffre, foi encarregado por Junot de arranjar Queluz, e Queluz tornou-se o que devia ser uma residência reservada ao homem que detinha o poder no país" 27 . Entre outras manifestações de cumplicidade política, salienta ainda o papel preponderante do corpo do comércio da cidade de Lisboa, cujas mais influentes figuras bem conhecia. Neste sentido, esclarece que "o comércio da cidade de Lisboa "reuniu então com diversas pessoas da alta nobreza" para formarem uma junta: esta compôs uma espécie de mensagem que foi apresentada ao duque de Abrantes para ser transmitida ao imperador Napoleão [...] Essa mensagem foi escrita por mão hábil, após ter sido traduzida em português e em francês, e aprovada por unanimidade, por todos os membros daquela assembleia"28.

Aparentemente urdida em conivência com Junot, a dita mensagem, assinada unanimemente "por cinquenta e duas assinaturas das mais notáveis do país, entre a nobreza e o comércio", contrariava as expectativas políticas do representante pessoal do imperador ${ }^{29}$, na medida em que nela se defendia a outorga Napoleónica de uma Constituição para Portugal. Integravam o grupo de afrancesados iluministas e liberais que redigiram a chamada "súplica de 1808" o médico Gregório José de Seixas, Ricardo Raimundo Nogueira, reitor do colégio dos nobres, Simão Cordes Brandão e Ataíde, professor de direito canónico na Universidade de Coimbra e Bento Pereira do Carmo, juiz de fora em Ançã e outros jurisconsultos. Tiveram igualmente papel de relevo na dinamização do grupo pelo menos dois

26 Duquesa de Abrantes, Recordações de uma estada em Portugal 1805-1806. Apresentação e notas de José-Augusto França, trad. de M. Figueiredo, Lisboa, BNP, 2008, p. 104.

27 Idem, ididem, p. 101. Embora transposto para o campo ficcional, mas com abundância de referências a fontes da época, veja-se o tratamento dado a esta questão por Raul Brandão, El-Rei Junot, Lisboa, IN-CM, 1982 (1ª ed. 1912).

28 Idem, ididem, p. 104.

29 A duquesa de Abrantes afirma mesmo que o documento em causa, pelo seu teor e pelo facto de ter sido subscrito por tão ilustres personalidades, "provocou náuseas ao pobre coração de Junot". E mais adiante revela que Junot conservou o documento nos seus papéis e que não o enviou, como se tinha comprometido perante os membros da Junta, a Napoleão, Idem, ididem, pp. 104-105. 
franceses: o oficial Henri Carrion d'Espagne Nisas e o influente industrial de Tomar Timóteo Lecussan Verdier ${ }^{30}$.

Em face do ficou exposto resta saber em que termos foi formulada a súplica dirigida a Napoleão? Que paradigma constitucional foi adotado? Que mecanismos de legitimação se previam? E que relação estabelecer entre o grupo que, em Lisboa, apresentou a "súplica constitucional" e a famosa deputação mandatada por Junot para, em Bayonne, junto de Napoleão, exprimir o "voto da nação" portuguesa?

A petição constitucional foi suportada por uma instituição corporativa de base representativa, a Junta dos Três Estados, que havia sido criada depois da Restauração de 1640 para administrar impostos militares. A sua reativação em 1808, num momento em que é lançada uma pesada contribuição de guerra, de 40 milhões de cruzados, tinha também subentendido o parecer de redução daquela exação fiscal, voto formulado diretamente pelos representantes portugueses a Napoleão, em Bayonne.

Em sessão de Junta, o juiz do povo apresentou então o documento em que se pedia a conservação do reino, um rei da família imperial e uma constituição política "que fosse em tudo semelhante à que o imperador havia outorgado ao Grão-Ducado de Varsóvia, "com a única diferença de que os representantes da nação sejam eleitos pelas câmaras municipais a fim de nos conformarmos com os nossos antigos usos", conforme se afirma ${ }^{31}$.

O paradigma moderno remete para a Constituição napoleónica do ano VIII, conjugando, porém, o propósito de mudança política com a tradição municipalista portuguesa e com a História recalcada da fundação do reino portucalense. Neste ponto, os autores da "súplica constitucional" recordavam, com manifesta parcialidade, serem os portugueses "de raça francesa, como descendentes dos que conquistaram este belo país aos mouros [...] que devem à França, sua mãe pátria, o benefício da independência que recobraram como nação em 1640". Esperavam assim que, sob a proteção do imperador, Portugal pudesse integrar, de pleno direito, o "sistema continental da família europeia"32.

\footnotetext{
30 Sobre a génese e a ação do grupo que defendeu a outorga napoleónica de uma Constituição para Portugal, veja-se, por todos, SILVA, Nuno J. Espinosa Gomes da, "Reflexão sobre a génese do chamado projeto de Constituição de 1808, a outorgar, por Napoleão, a Portugal”, Direito e Justiça, vol. XVIII, 2004, t, II, pp. 39-186.

31 ARAÚJO, Ana Cristina, ob. cit., p. 75.

32 Idem, ibidem.
} 
Deste diálogo entre tradição e modernidade no plano constitucional permaneceu o corpo de princípios e direitos que matizou, no essencial, o constitucionalismo monárquico português do século xıx, de filiação cartista.

Se não vejamos: a "súplica de 1808" erigiu como princípios fundamentais do Estado de direito a igualdade civil e fiscal, a liberdade de opinião e de imprensa, o direito à propriedade, o direito à instrução e a liberdade de cultos. Em matéria de liberdades, direitos e garantias, contemplava, expressamente, a supressão da escravatura, a extinção dos bens de mão morta e a abolição de privilégios estamentais, respeitando-se estritamente o Código Civil Napoleónico.

No plano do ordenamento político, propunha a criação de um ministério da instrução pública e a separação dos três poderes (executivo, judicial e legislativo). O poder legislativo ficaria a cargo de duas câmaras, sendo exercido em "concorrência da autoridade executiva". Recorde-se que a atribuição do poder legislativo a duas câmaras foi acolhida na Carta Constitucional de 1826 e na Constituição de 1838, assim como o primado da outorga régia sobre a ação do poder de uma assembleia constituinte.

A "súplica constitucional" de 1808, salvaguardava a independência do poder judicial, o princípio da responsabilidade ministerial e apontava para uma reforma político-administrativa à francesa, mas em que as colónias portuguesas, tomadas como parte integrante do reino, fossem "consideradas como províncias ou distritos". Do ponto de vista das relações entre o Estado e a Igreja, propunha a adoção de uma religião de Estado: a Católica Apostólica Romana. No respeito pela concordata celebrada entre Napoleão e a Santa Sé (1801), garantia, no entanto, a liberdade religiosa e de culto público a todos os outros credos, o que, entre nós, só viria a acontecer, plenamente, depois da implantação da República, em 1910.

Em síntese, os direitos, liberdades e garantias que deviam constar de uma carta constitucional, elaborada nos mesmos moldes da que Napoleão outorgara ao Grão-Ducado de Varsóvia, compaginavam-se, como vimos, com a exigência de aplicação do Código Civil francês. Outra nota importante é a de que a renúncia da via revolucionária assentava no pressuposto de que as mudanças em curso deveriam ser conduzidas pela elite afrancesada. Esta tentativa de precipitar a mudança por meio da adoção de um constitucionalismo moderado, imposto a partir de cima, punha em causa as estruturas do Antigo Regime e 
as bases tradicionais da monarquia portuguesa, mas não a conceção orgânica de nação.

Partindo do modelo de constitucionalização assente num ato de outorga que, na ordem política, se sobrepunha ao direito de conquista, os afrancesados constitucionais alavancavam o princípio da representação na organização concelhia, ou seja, no poder de representação dos concelhos que, de acordo com a tradição, tinham assento em Cortes. O envolvimento histórico-constitucional dos concelhos na construção do Estado de direito a outorgar por Napoleão começou por ser caucionado pela divulgação oficial a todos os municípios do país da "súplica constitucional" e da carta enviada pela "deputação de Bayonne". Em Maio de 1808 são muito significativas as actas de vereação das câmaras municipais nortenhas que, em louvor da "benevolência de Napoleão, registam a tomada de conhecimento e a suposta adesão dos povos às reivindicações de mudança política avançadas por outros representantes da nação ${ }^{33}$.

Como recentemente sublinhou Fernando Catroga, muitos dos propósitos enunciados em 1808 estiveram no centro do debate político português do século $\mathrm{XIX}^{34}$. As ideias defendidas em 1808 eram patrióticas e de alcance revolucionário, ainda que desprovidas dos alicerces representativos que o liberalismo acabou por consagrar. Quando surgiram foram rejeitadas, eram demasiado avançadas, postulavam a abdicação da casa de Bragança e foram mal vistas pelos sectores tradicionais, não pelo mesmo motivo, pois havia uma fação da nobreza que apoiava as aspirações de Junot à Regência do reino, mas porque subentendiam a abolição de ancestrais privilégios. Representado pelo conde da Ega e seus seguidores, um importante sector da nobreza aderiu à conceção ordeira do regime bonapartista, encarando-o mais como conciliador dos antigos e dos modernos, do que como continuador da revolução de 1789.

Mesmo não sendo os afrancesados um grupo ideologicamente coeso, sobre ele impendia a frequente acusação de dissenso e traição ao governo do reino. Portanto, depois da expulsão dos invasores foi preciso calar humilhações e salvaguardar a honra, o que começou por acontecer de forma impessoal e ao

33 CAPELA, José Viriato et. al, O Heróico Patriotismo das Províncias do Norte. Os Concelhos na Restauração de Portugal de 1808, Braga, Casa Museu de Monção/Universidade do Minho, 2008.

34 CATROGA, Fernando, "Em Nome da Nação", in Fernando Catroga e Pedro Tavares de Almeida (coord), RES PUBLICA. Cidadania e Representação Política em Portugal, 1820-1926. Lisboa, Assembleia da República/Biblioteca Nacional de Portugal, 2010, pp. 36-38. 
mais alto nível. A Convenção de Sintra, ao regular as condições de evacuação do exército invasor, previra, no seu artigo XVII, que nenhum súbdito da monarquia seria considerado politicamente responsável, ou seja, que nenhum português responderia autonomamente pela sua conduta política, durante o período de ocupação francesa. Reconhecia-se, assim, que a obediência dos cidadãos portugueses ao governo francês não radicava, exclusivamente, na vontade dos indivíduos mas no cumprimento das ordens deixadas pelo príncipe D. João, aquando da partida da Corte para o Brasil. Neste quadro, não seria justo incriminar pessoas e causar dano a seus bens e propriedades. Por isso, em última análise, admitia-se que aqueles que continuaram no exercício dos seus empregos, ou que serviram o governo francês, pudessem ser protegidos pelos comandantes britânicos. Na realidade, não foi isso que aconteceu. As perseguições aos chamados "afrancesados" iniciaram-se logo após a expulsão dos invasores e afetaram a reputação de importantes figuras públicas.

Com a sanção formal da Corte portuguesa, sediada no Rio de Janeiro, é reinstalada, a 18 de setembro de 1808, a Regência sem quatro dos seus iniciais membros: D. Francisco Rafael Castro (principal da Igreja Patriarcal de Lisboa, ex-reitor e reformador da Universidade, conselheiro de Estado e regedor da Justiça), Pedro de Melo Breyner (ex-governador das Justiças e presidente do Real Erário), o conde de Sampaio - os três afastados por estreita colaboração política com os franceses - e ainda o marquês de Abrantes, que ficara em França depois de ter sido enviado com a delegação que fora prestar obediência, em nome da nação portuguesa, a Napoleão em Bayonne. Estes lugares vagos foram preenchidos pelo bispo do Porto - pouco depois elevado à categoria de patriarca eleito e que assume a presidência da Regência -, pelo conde de Castro Marim, pelo marquês das Minas e por Dom Miguel Pereira Forjaz, nomeado secretário dos Negócios Estrangeiros e da Guerra.

O governo do Reino intensifica a partir de então a caça aos afrancesados. E em dois momentos cruciais da guerra, que coincidem com o início da segunda invasão, em março de 1809, e com o avanço das tropas de Massena, em setembro de 1810, têm lugar as mais cruéis vagas de denúncias e prisões de dissidentes, intelectuais, maçons e afrancesados políticos. Em 1810, cerca de meia centena de indivíduos, vulgarmente designados "setembrizados", foram presos sem culpa formada e deportados para os Açores. Algumas das mais destacadas figuras deste 
grupo contaram com o apoio da maçonaria britânica e obtiveram passaporte do Foreign Office para se estabelecerem em Inglaterra e aí permaneceram em exílio forçado ${ }^{35}$. Este episódio provocou forte indignação na opinião pública britânica e suscitou também a crítica veemente de publicistas portugueses exilados no estrangeiro, como Bernardo da Rocha Loureiro, diretor do jornal O Portuguez, Hipólito Cardoso da Costa, autor e responsável pela distribuição do Correio Braziliense e José Liberato Freire de Carvalho, redator do Investigador Português em Inglaterra, entre outros autores.

A clarificação das divisões ideológicas entre os defensores da França e de Inglaterra foi-se aprofundando no decurso da guerra. Durante a ocupação do Porto por Soult, em 1809, os afrancesados e as elites esclarecidas daquela cidade procuraram retomar, dentro do modelo constitucional bonapartista, as propostas anteriormente defendidas de transformação do Estado e da sociedade. As divisões políticas minavam a confiança dos cidadãos no governo local. Depois de 1808, ficara claro que havia na vereação da câmara do Porto elementos comprometidos com a causa francesa. O procurador da cidade, Manuel Félix Correia da Maia, e dois vereadores, José de Sousa Melo e Joaquim de Vasconcelos Cardoso Meneses, sofreram represálias políticas, foram afastados e o procurador depois de libertado do cárcere foi banido do exercício de funções ${ }^{36}$. Na sequência dos episódios sangrentos de 29 de março, das mortes, roubos e perseguições que ocorreram aquando da entrada do exército de Soult na cidade do Porto, os franceses relançam a propaganda política tentam alargar a sua base de apoio social.

A discussão sobre a ilegitimidade da casa de Bragança à coroa portuguesa é agora discutida abertamente, com o argumento de que a fuga da Corte

35 Beneficiaram inicialmente deste tratamento: o antigo grão- mestre da maçonaria portuguesa Sebastião de Sampaio, o bacharel em leis José Sebastião de Saldanha de Oliveira e Daun, senhor de Pancas, neto do marquês de Pombal, o naturalista Domingos Vandelli,, negociante de origem francesa Jacôme Ratton, o negociante Bento Dufourq, o médico António de Almeida, o magistrado José Diogo de Mascarenhas Neto e os pintores italianos Pellegrini e Pizetti. Sobre a Setembrizada, veja-se a bibliografia disponível e a relação circunstanciada dos presos e deportados apresentada por A H. de Oliveira Marques, História da Maçonaria em Portugal, vo. 1. Das origens ao triunfo, Lisboa, Editorial Presença, 1990, pp. 100-102. Existe também na BNL, códice 855, fl. 349-350, uma lista de nomes de "jacobinos mandados sair de Lisboa, como incorrigíveis e teimosos, 1810-1811-1812", referenciada por Lúcia Maria Bastos Pereira das Neves, Napoleão Bonaparte. Imaginário e política em Portugal c. 1808-1810, São Paulo, Alameda, 2008, p. 218.

36 SILVA, Francisco Ribeiro da, "A cidade do Porto nos finais de setecentos e as circunstâncias da segunda Invasão Francesa" in AAVV. O Porto e as Invasões Francesas. 1809-2009, Porto, Público-CMP, 2009, vol. 2, pp. 147 e ss.. 
para o Brasil significara, em termos práticos, a abdicação do cetro português. Recorde-se que a ideia de violação do pacto político, entre o monarca e os seus súbditos, já havia sido denunciada pelo juiz do povo, José de Abreu Campos, por ocasião da reunião da Junta dos Três Estados. Na presença de Junot, a vacância do trono português tinha sido discutida não em termos de direito mas em termos de facto, pois o juramento de obediência e fidelidade fora firmado com a rainha Dona Maria, ainda viva. Na ausência da realeza, cabia ao povo, representado pelos seus procuradores em Cortes, verificar se D. João, ao partir para o Brasil, violara ou não as leis fundamentais do reino. É que a ideia de um rei manietado e enganado pelos seus ministros não garantia a perenidade do seu governo.

Retomando esta questão, vem a público, em 1809, o Desengano proveitoso que um amigo da pátria se propõe dar aos seus concidadãos (1809), texto atribuído a Frei António de Santa Bárbara. O seu presumível autor, religioso da Congregação dos Agostinhos Reformados, bacharel em Filosofia e Matemática e professor régio de Filosofia, pronuncia-se em nome da pátria e em defesa da soberania nacional e avança novos argumentos a favor da liberalização do regime político em Portugal, sustentando a inevitabilidade da queda do absolutismo, o carácter usurpatório da proteção inglesa e a derrocada do partido dos áulicos em Portugal. Propunha assim que a nação pudesse exprimir a sua adesão ao domínio napoleónico, reconhecendo o duque da Dalmácia, como rei de Portugal ${ }^{37}$.

$\mathrm{Na}$ génese daquele projeto estava a ideia de que o reino fora confiado a um "governo cobarde e inepto", "composto de fidalgos que aprenderam a política entre divertimentos de jogo e de caça” e a convicção de que o príncipe [com o abandono do reino] renunciara, "espontaneamente, o direito à Coroa de Portugal" 38. Logo, a acusação pública de um governo de "estúpidos, sem energia,

\footnotetext{
37 Desengano Proveitoso, que hum amigo da Patria se propoem dar aos seus concidadãos, Porto, Typ. de Antonio Alvarez Ribeiro, 1809. Sobre o presumível autor do Desengano Proveitoso veja-se, para o período vintista, o que escreve TAVARES, Pedro Vilas Boas, "A Pregação ao Serviço da Revolução: O Porto e a instauração do liberalismo num sermão de Fr. António de Santa Barbara”, Revista da Faculdade de Letras do Porto. Linguas e Literaturas, II Série, vol. IV, 1987, pp. 43-74.

38 Desengano Proveitoso, que hum amigo da Patria se propoem dar aos seus concidadãos... cit., pp. 11 e 15 .
} 
sem talentos e sem patriotismo" 39 assentava no postulado ideológico da falta de legitimidade do mesmo governo para manter a independência da nação.

A defesa do princípio da "vagatura do trono português" e a consideração da existência de um "governo fanático, ilegal e nulo" suscitam, portanto, a discussão da legitimidade da soberania política. Na linha do abade de Sieyès, o autor do Desengano proveitoso que um amigo da pátria se propõe dar aos seus concidadãos postula, com base no primado conferido ao contrato social, a possibilidade de a nação poder assumir-se como sujeito constituinte. O seu objetivo é o de alicerçar a nação no império da lei, entendida esta como expressão da vontade geral, conforme o modelo francês de 1789. Neste sentido, escreve: "As leis fundamentais da monarquia não permitem que o príncipe trespasse a coroa a sujeito da sua amizade. Se o príncipe legítimo existe governe ele; se não existe, a coroa cai de novo na mão dos povos, que, sós, a podem dar a varões prestantes. Em toda a parte a soberania não é património particular dos príncipes, mas um depósito sagrado que se lhes confiou para promoverem e não arruinarem a fortuna pública” ${ }^{4}$.

De forma mais enfática do que em 1808, o discurso político afrancesado ganha um leve acento republicano, na forma como equaciona o superior interesse público. A linguagem da moderna cultura política afrancesada, indissociável da expressão da vontade geral através da opinião pública, alicerça-se no confronto de pareceres doutrinalmente fundamentados sobre o Estado e os direitos da realeza e encontra eco nos espaços e meios que funcionam como grandes mediadores da modernidade política: os periódicos e a imprensa em geral, os clubes, as associações e as lojas maçónicas.

Em prol do exercício da liberdade pensamento, a crítica dos sectores conservadores esclarecidos tornava também irrefutáveis alguns dos traços de desunião que atravessam a fraternidade maçónica. O maçon José Máximo Pinto da Fonseca Rangel, oficial de infantaria do exército português, que dirigira, em 1808, o Conselho Conservador de Lisboa, organização secreta constituída para travar a escalada do poder francês e lutar pela paz geral, assumiu, em 1809, a oposição pública à corrente política afrancesada. Antes de ser preso, em 1810,

39 Idem, ibidem, p. 12.

40 Idem, ibidem, p. 15. 
acusado de traição e de envolvimento em atividades conspirativas, Máximo Pinto da Fonseca Rangel publicou um opúsculo de refutação ao Desengano Proveitoso, intitulado Analyse Severa e Refutação Cabal (1809) ${ }^{41}$. Em estilo de vigorosa polémica, e inspirado pelas Reflections on the Revolution in France (1790) de Edmund Burke, repudia a universalidade da razão revolucionária assente na destruição da propriedade em nome da igualdade, na desordem social em nome dos direitos individuais e no triunfo do ideal republicano em nome da justiça. Alinhando pela defesa do pensamento liberal conservador, recupera a ideia de que as instituições sem passado e as aspirações coletivas sustentadas à margem de qualquer tradição não só eram historicamente inviáveis como ilegítimas, tendo neste aspeto especialmente em conta o direito de conquista praticado pelos invasores franceses. Por isso escreve: "Os francezes tem ficado victoriosos de todas as Nações, exceto de Inglaterra; mas o bom sucesso das suas armas bem longe de provar a justiça da sua causa, só prova o estranho delírio e a fatal ilusão dos Povos que continuavão a crer que o remédio de seus males lhes podia vir de França”².

A rejeição dos pressupostos ideológicos do bonapartismo é pautada pelo princípio de que nenhum Estado "pode avassalar a soberania" de outras nações em nome de uma qualquer conceção territorial de Império. Logo, a "Europa das Nações", que começava a despertar do pesadelo napoleónico, para restaurar a paz e o equilíbrio das relações externas entre os Estados carecia do apoio de Inglaterra ${ }^{43}$. Perante a incógnita do desfecho do curso político dos acontecimentos em Espanha e Portugal, Máximo Pinto da Fonseca Rangel manifesta-se pois a favor do fortalecimento do governo nacional, sob domínio da casa de Bragança e mediante a ajuda externa da Grã-Bretanha. A retirada do príncipe regente para o Brasil, entrevista com tábua de salvação da monarquia e como condição de independência do reino, não era, em seu entender, irregular, ilegítima ou

41 Foi publicado também anonimamente com a seguinte referência completa: Analyse Severa e Refutação Cabal de bum folheto impresso no Porto em Abril de 1809 na Officina de Antonio Alvares Ribeiro, com licença do governo intruso; e que tem por titulo Desengano Proveitoso, que hum amigo da Patria se propõe dar aos seus concidadãos, Lisboa, na Impressão Régia, 1809.

42 Analyse Severa e Refutação Cabal...cit., p. 10

43 "Se alguma cousa se deve lançar em rosto às Nações da Europa, he não cooperarem com todas as suas forças juntas com as d'Inglaterra para debellar essa França”, Analyse Severa e Refutação Cabal...cit., pp. 13-14. 
aviltante para a pessoa do príncipe, conforme sustenta em resposta ao autor do Desengano Proveitoso ${ }^{44}$.

Considerado "temível conspirador" pelos absolutistas e inimigo dos jacobinos pelos liberais, Máximo Pinto da Fonseca Rangel foi-se revelando um liberal moderado, partidário da soberania partilhada entre o rei e a nação. Nessa qualidade participou na conspiração de Gomes Freire de Andrade em 1817 e na revolução de 1820. Em contrapartida, frei António de Santa Bárbara manteve-se fiel à matriz revolucionária francesa, de lastro radical e jacobino, participando como cidadão, sem assento em Cortes, nas trincheiras do liberalismo vintista ${ }^{45}$.

\section{Memórias de um tempo amordaçado}

À margem dos mecanismos de imposição de uma opinião pública refratária ao regime, expressa em registos de linguagem política diferenciados, assinale-se que a leitura oficial dos processos de afrancesamento das elites portuguesas não coincide, em absoluto, com a perspetiva histórica do autor que mais contribuiu para fixar a memória histórica da guerra e da resistência, José Acúrsio das Neves. Este autor, realista e conservador, não isenta de responsabilidade política algumas das mais altas dignidades, eclesiásticas e civis que, a mando de Junot, se deslocaram a Bayonne, para saudar Napoleão. Desconfia das intenções patrióticas reclamadas por alguns membros que integraram aquela deputação e considera mesmo hostis e antipatrióticas outras manifestações ideológicas subsequentes de adesão ao bonapartismo ${ }^{46}$.

44 Retoma a seguinte asserção: "O Príncipe do Brasil nasceo em Lisboa; e as Leis, que se lhe punhão nas mãos o Sceptro Portuguez, tirarão-lho logo que S. A. se retirou do nosso seio”. E, mais à frente, procura impugná-la com o argumento de que "As leis que a dão a S. A. são as fundamenates do Reino, bem especificadas nas Cortes de Lamego; e nem nellas se estabelece, nem ninguém jamais disse que ao sahir o Soberano do Reino por causa da guerra" punha em causa o "direito à Coroa", Analyse Severa e Refutação Cabal...cit., pp. 30-31.

45 SANTA BÁRBARA, Fr. Antonio de, Sermão de Acção de Graças pela desejada e muito feliz união da Junta Provisória do Governo Supremo do Reino com o Governo Interino de Lisboa, verificada no $1^{\circ}$ de Outubro de 1820, s.n.s.d.. Sobre o tema veja-se, TAVARES, Pedro Vilas Boas, ob. cit.

46 ARAújO, Ana Cristina, "Memória e Mitos da Guerra Peninsular em Portugal. A 'História Geral da Invasão dos Franceses' de José Acúrsio das Neves”, Revista de História das Ideias, vol. 29, 2008, pp. 241-274. 
Recorde-se que na época, as palavras pátria e patriota e os seus antónimos eram recorrentes no discurso político. Em geral, o patriotismo traduzia as mais legítimas aspirações de libertação coletiva, de filiação e de pertença a um destino comum, de ordem e de fidelidade. Para a maioria, a pátria comum, no sentido étnico-religioso e histórico, tinha a sua expressão mais elevada na aliança do povo à religião e ao rei. Para o escol político afrancesado a pátria comum, ou seja, "o sistema continental da família europeia", fundava-se no império da lei e na aspiração futurante da liberdade, com raízes míticas no passado e na fundação do reino, tal como reivindicavam.

Num campo como noutro, existiam patriotas, homens que pautavam, com abnegação e virtude, a sua conduta por modelos ético-políticos diferentes. Por isso, o termo patriota tanto era usado para caracterizar a lealdade e a bravura de elementos anónimos do povo que se singularizavam em campanhas de resistência contra o invasor, como para exprimir a singularidade das ações de indivíduos civis ou religiosos com poder de representação, fiéis às leis da res publica e aos ideais da "pátria cívica", à maneira da Revolução Francesa.

$\mathrm{Na}$ esteira de Fernando Catroga, pensamos que o primeiro nível de patriotismo tem uma forte componente comunitarista, componente essa que se pode articular com a escolha livre dos cidadãos, ou seja, com um patriotismo "polarizado, dominantemente, por valores jurídico-políticos, perspetiva que, reatualizada, virá a ser fundamentadora da ideia de patriotismo cívico de raiz contratual e, por extensão e transformação, do conceito moderno de 'nação cívica'. Por sua vez, embora a primeira aceção pudesse coabitar com a segunda, ela funcionará, sobretudo, como o molde por excelência, quer da conceção mais holística, étnico-cultural e territorial dos sentimentos de pertença, quer da sua expressão mais totalizadora como "nação orgânica" 7 .

Os alicerces da conceção de nação orgânica são, por seu turno, indissociáveis da visão histórica da guerra. No relato histórico que José Acúrsio das Neves construiu das Invasões Francesas, nota-se que o pathos emocional da revolta sublima a virtude do povo e o horror causado pelo impacto brutal e sangrento da chacina perpetrada a gente inocente e totalmente desprotegida. Reportando-se

47 CATROGA, Fernando, "Pátria, Nação, Nacionalismo", in Luis Reis Torgal, Fernando Tavares Pimenta, Julião Soares Sousa (coord.). Comunidades Imaginadas, Nação e Nacionalismos em África, Coimbra, Imprensa da Universidade, 2008, p. 13. 
ao fuzilamento ocorrido em Leiria, no sítio da Portela, a 5 de Julho de 1808, fala da "mais horrível carniceria de que havia memória, concentrando o seu olhar na aflição provocada pela violência armada e na irremediável reparação de dois sobreviventes ${ }^{48}$.

Magistral na construção visual de uma execução de guerra, convertida em martírio para um sobrevivente, escrevendo sem artifício e utilizando apenas a emoção e a naturalidade para exprimir os acontecimentos, Acúrsio das Neves coloca os heróis e as vítimas das Invasões Francesas, sem distinção de hierarquia, estado ou condição, no mesmo pedestal. O seu lema é claro: "os libertadores da pátria são dignos de recomendar-se ao reconhecimento do soberano e da nação, e os seus nomes de serem transmitidos à posteridade com a glória que lhes é devida" ${ }^{\prime \prime}$.

Do ponto de vista da memória, o ardente patriotismo do autor que seculariza e dessacraliza a História da guerra é o mesmo que confere um toque martirológico aos heróis da narrativa. Esta "transferência de sacralidade" 50 funciona como garantia de segurança para os sobreviventes e como cenário ideal para o aparecimento de novos cultos cívicos, em torno dos mártires da liberdade e dos heróis da guerra, que tardaram, no entanto, a impor-se em Portugal.

Na verdade, no termo da guerra, foi duplo o silêncio que se abateu sobre os acontecimentos e os seus reais protagonistas: perseguidos, mortos, sobreviventes e desaparecidos. Muitos dos arautos da mudança política que em 1808 tomaram a palavra sofreram perseguições, alguns foram presos e outros deportados para Inglaterra. Dos dois lados da barricada, as vozes das elites e os atos de rebeldia do povo foram recalcados ou mesmo banidos da memória coletiva. A resistência e a insubmissão do povo indefeso significava a falência temporária das autoridades que representavam o despotismo régio. A sua lembrança, nos anos seguintes, não deixava, por isso, de constituir uma provocação para os caudilhos político-militares ao serviço da Coroa.

\footnotetext{
48 ARAÚJO, Ana Cristina, "Ocupação e Resistência na Guerra Peninsular. O Massacre de 5 de Julho de 1808, em Leiria”, Revista de História das Ideias, vol. 31, 2010, pp. 151-188.

49 NEVES, José Acúrsio das, História Geral da Invasão dos Franceses em Portugal e da Restauração deste Reino (1808-1810), in Obras Completas, (Estudos introdutórios de António Almodovar e Armando de Castro), Porto, Edições Afrontamento, 1984, t. I, pp. 143-144.
}

50 OZOUF, Mona, La fête révolutionaire (1789-1799), Paris, Gallimard, 1976. 
À política da memória contrapôs-se, portanto, a necessidade de organização do esquecimento, condição essencial para que se forjasse a ilusão necessária de continuidade do poder e de unidade da nação. A persistente linha de silêncio em que estancou e se suspendeu a evocação histórica tradicional deste período seminal da nossa conturbada e indecisa contemporaneidade tem escamoteado não as questões da guerra mas os problemas da difícil unidade política da resistência. Uma das chaves para a compreensão da subalternidade conferida aos testemunhos ideológicos e pessoais dos portugueses que passaram pelas trincheiras da resistência prende-se com o medo, por muitos sentido, de ajustes de contas imediatos e de represálias posteriores, durante o período revolucionário e no decurso das lutas entre liberais e miguelistas.

No interior das famílias guardavam-se segredos e ocultavam-se verdades difíceis de pronunciar em público. A casa de Almeida Garrett não escapava à regra. As Invasões Francesas haviam provocado alterações de monta na pacata vida familiar do futuro escritor. Com a guerra à porta, em vésperas da entrada de Soult na capital nortenha, António Bernardo da Silva, selador-mor da Alfândega do Porto, deixa para trás os seus negócios na urbe, um rico património e uma vida de abastança tipicamente burguesa, para abraçar, sem perda de dignidade e ventura, a mansidão de uma existência pacata nos Açores, em companhia de sua mulher, D. Ana Augusta de Almeida Leitão e dos filhos do casal. O pequeno João Baptista da Silva Leitão, então com nove anos de idade, prossegue em Angra os seus estudos sob a exigente e esclarecida batuta do tio paterno, o bispo D. Frei Alexandre da Sagrada Família ${ }^{51}$.

O reduto familiar alargou-se com a chegada do magistrado João Carlos Leitão à ilha para exercer, a partir da Graciosa, o cargo de provedor dos resíduos e capelas dos Açores ${ }^{52}$. Este tio materno de Garrett, que acompanhara a primeira revolta do Porto, conhecia bem a história de um dos mentores militares dos levantamentos de 7 e de 18 de Junho, que acabou por ser julgado e sentenciado como traidor, mais tarde. Publicou em sua defesa uma Ode ao Senhor Manuel Mariz Sarmento, Capitão de Artilharia, em memoria do arrojado e glorioso

51 Devemos o conhecimento em filigrana das origens familiares do escritor, a que fazemos referência, à obra fundamental de MONTEIRO, Ofélia Milheiro de Paiva Caldas, A Formação de Almeida Garrett. Experiência e Criação, Coimbra, Centro de Estudos Românicos, 1971.

52 Idem, ibidem, p. 42 
denodo com que sacudio da cidade do Porto o jugo francez no dia 18 de Junho de 1808 e celebrou a libertação da cidade com outra Ode em obsequio à Nação Britanica, por gratidão aos poderosos, e efficazes socorros com que contribuiu para a feliz Restauração de Portugal (1808).

O eco das notícias que chegavam do reino tornou-se assim mais vibrante na presença do testemunho emotivo e do juízo político de uma voz próxima dos acontecimentos. Paralelamente, o círculo de opinião formado pelos exilados na ilha, os "setembrizados", não deixava de ter alguma projecção no seio de uma família rica "em virtudes religiosas e civis", de acordo com retrato fornecido pelo próprio escritor.

Com a consciência do mundo que perdera, o jovem Garrett, sentindo-se tocado pelos sonhos desfeitos de uma geração e pelo fulgor dos ideais que faziam mover homens, povos e nações, torna-se "admirador secreto do Corso, cujo vulto lhe seduzira a imaginação trabalhada pelo cavaleiresco fantástico das histórias antigas e das lendas populares" ${ }^{\prime 3}$. Projeta essa precoce idealização da figura de Napoleão numa passagem das Viagens na minha Terra em que o narrador começa por confessar "ter pena de nunca ter visto o Junot nem o Maneta" - personagens que à distância terão ficado gravadas na memória juvenil de Garrett. E, logo a seguir, no ardor dos sentimentos e lembranças que causavam "inguiço" lá estava Bonaparte, que por "por excitar tantos ódios e malquerenças, era necessário que fosse um bem grande homem" ${ }^{\prime 55}$.

Para quebrar de vez o enguiço, o retrato de Napoleão de tempos idos, furtivamente capturado à balbúrdia da feira de S. Lázaro, no Porto, comparece assim no romance como ícone de um mal de juventude que deixara marcas profundas no imaginário político de uma geração.

\footnotetext{
53 Idem, ibidem, p. 41.

54 ALMEIDA GARRETT,Viagens na minha Terra. Edição crítica de Ofélia Paiva Monteiro, Lisboa, IN-CM, 2010, cap. IX, p. 153.

55 Idem, ibidem.
} 